\title{
PENGARUH DANA PIHAK KETIGA DAN NON PERFORMING FINANCING TERHADAP PEMBIAYAAN MUSYARAKAH
}

\author{
Debbi Chyntia Ovami ${ }^{1)}$ Ayu Azillah Thohari ${ }^{2)}$ \\ Universitas Muslim Nusantara Al-Wasliyah \\ Program Studi Akuntansi \\ debbichyntia@gmail.com
}

\begin{abstract}
Abstrak
Penelitian ini bertujuan untuk mengetahui pengaruh Dana Pihak Ketiga (DPK) dan Non Performing Financing terhadap Pembiayaan Musyarakah pada Bank Syariah Mandiri KCP Medan Sukaramai. Populasi pada penelitian ini berjumlah sebanyak 36 bulan yaitu Data Pembiayaan Musyarakah Bank Syariah Mandiri Tahun 2014-2016. Teknik pemilihan sampel dalam penelitian ini adalah sampel jenuh. Teknik analisis data yang digunakan regresi linier berganda. Hasil penelitian menunjukkan bahwa secara parsial Dana Pihak Ketiga berpengaruh negatif dan tidak signifikan terhadap Pembiayaan Musyarakah, Non Performing Financing berpengaruh negatif dan signifikan terhadap Pembiayaan Musyarakah dan secara simultan menunjukkan bahwa Dana Pihak Ketiga dan Non Performing Financing berpengaruh terhadap pembiayaan musyarakah.
\end{abstract}

Kata kunci : dana pihak ketiga, non performing financing, pembiayaan musyarakah

\begin{abstract}
This study aims to determine the effect of Third Party Funds (DPK) and Non Performing Financing on Musyarakah Financing at Bank Syariah Mandiri KCP Medan Sukaramai. The population in this study amounted to 36 months ie Musyarakah Financing Data Bank Syariah Mandiri Year 2014-2016. Sample selection technique in this research is saturated sample. The data were processed by using multiple linear regression tests. The results showed that partially of Third Party Fund had negative and did not have significant influence on Musyarakah Financing, Non Performing Financing had negative and significant influence on Musyarakah Financing and simultaneously showed that Third Party Fund and Non Performing Financing effect on musyarakah financing.
\end{abstract}

Keyword : third party funds, non performing financing, musyarakah financing

\section{PENDAHULUAN}

\subsection{Latar Belakang}

Perbankan syariah menjadi alternatif sistem perbankan yang memiliki berbagai macam produk dan pelayanan yang beragam akan siklus operasionalnya serta memiliki kemampuan menghasilkan profit menjadi indikator penting untuk keberlanjutan entitas bisnis dan untuk mengukur kemampuan bersaing dalam jangka panjang. Di tengah ketidakstabilan ekonomi saat ini dan masih kurangnya tingkat kepercayaan masyarakat terhadap institusi moneter, Bank Syariah tetap dapat mampu berdiri tegak di tengah berbagai terpaan rintangan dan persaingan yang terjadi. Potensi yang besar tersebut memacu institusi 
perbankan syariah sendiri untuk lebih kreatif, inovatif, dan terorganisir dengan profesional. Bank Syariah diharapkan mampu menjawab segala harapan akan pentingnya sistem Islam diterapkan dalam dunia perbankan. Hal tersebut dapat diwujudkan melalui peningkatan kualitas produk yang dimilikinya. Para praktisi perbankan mengetahui bahwa bank syariah memiliki produk-produk yang sangat bervariatif. Berbeda dengan bank konvensional yang hanya berfokus pada produk tabungan deposito, dan penyaluran dana secara kredit, bank syariah memiliki produk lebih banyak dan beragam. Seperti salah satunya adalah musyarakah.

Menurut Naf'an (2014:95), musyarakah adalah akad kerjasama antara dua pihak atau lebih untuk suatu usaha tertentu, dimana masingmasing pihak memberikan kontribusi dana dengan tujuan mencari keuntungan. Apabila usaha tersebut untung maka keuntungan akan dibagi berdasarkan kesepakatan didalam perjanjian. Apabila usaha tersebut rugi maka kerugian akan dibagi berdasarkan porsi kontribusi dana. Bank Syariah Mandiri merupakan salah satu bank konvensional yang

membuka bank syariah, memberikan berbagai jasa perbankan diantaranya pembiayaan mudharabah, murabahah, musyarakah dll. Sebelum memberikan pinjaman kepada para nasabah terlebih dahulu pihak bank akan melakukan pemantauan secara lebih intensif. Meningkatnya total pembiayaan musyarakah Bank Umum Syariah dan Unit Usaha Syariah tidak terlepas dari kegiatan pengimpunan dan penyaluran dana termasuk di dalamnya Bank Syariah Mandiri.

Pertumbuhan aset yang dimiliki BSM tidak terlepas dari peningkatan pembiayaan serta jumlah dana pihak ketiga yang terhimpun. Dalam kaitannya dengan penyaluran dana atau pembiayaan terdapat beberapa faktor yang menentukan pembiayaan musyarakah. Faktor tersebut yaitu kemampuan dalam menghimpun dana terutama dalam hal ini adalah Dana Pihak Ketiga ( DPK ) dan kualitas pembiayaan dalam hal ini adalah pembiayaan bermasalah atau Non Performing Financing ( NPF ). Berikut ini adalah jumlah pembiayaan musyarakah pada Bank Syariah Mandiri KCP Sukaramai tahun 2015.

Tabel 1.1

Jumlah Pembiayaan Musyarakah

\begin{tabular}{|l|l|l|}
\hline No. & Tahun & Jumlah Pembiayaan Musyarakah \\
\hline 1 & 2014 & Rp. $1.000 .000 .000,00-$ \\
\hline 2 & 2015 & Rp. 727.390.000,00- \\
\hline 3 & 2016 & Rp. 700.000.000,00- \\
\hline
\end{tabular}

Sumber : Data Bank Syariah Tahun (2015)

Dari Tabel 1.1 diatas dapat kita lihat jumlah pembiayaan musyarakah yang cukup besar nominalnya. Antara tahun 2014-2016 terjadi penurunan dana pembiayaan musyarakah terhadap nasabah dikarenakan permintaan pembiayaan musyarakah sesuai dengan usaha yang dijalankan. Untuk itu peneliti tertatik untuk melakukan penelitian yang berjudul'Pengaruh Dana Pihak Ketiga dan Non Performing 
Financing Terhadap Pembiayaan

\subsection{Tujuan}

Berdasarkan uraian latar belakang dan perumusan masalah, maka tujuan penelitian ini adalah untuk mengetahui dan menganalisis pengaruh dana pihak ketiga dan non performing financing terhadap pembiayaan musyarakah secara parsial dan simultan pada Bank Syariah Mandiri KCP Sukaramai.

\subsection{Pendekatan Pemecahan Masalah}

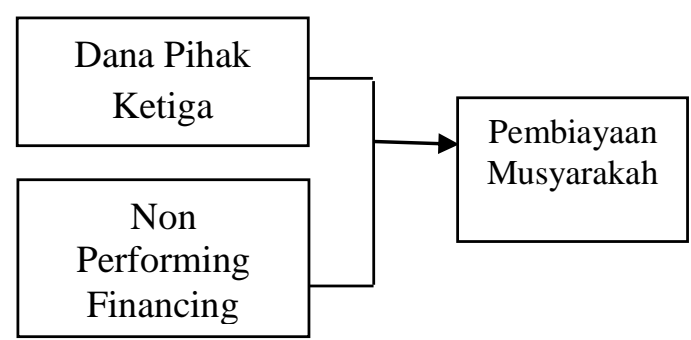

Gambar 2.1

\section{Kerangka Konseptual}

Berdasarkan kerangka konseptual, dapat diketahui bahwa variabel independen dalam penelitian ini adalah Dana Pihak Ketiga dan Non Performing Financing sedangkan variabel dependennya adalah Pembiayaan Musyarakah.

\section{METODE}

Model analisis data yang digunakan pada penelitian ini adalah model analisis regresi linier berganda. Tujuan dari teknik analisis regresi linier berganda adalah untuk melihat secara langsung pengaruh beberapa variabel terikat (Erlina, 2011:111).Untuk menguji hipotesis, digunakan Model Regresi Linier Berganda dengan rumus sebagai berikut:
Musyarakah”.

$$
Y=b_{0}+b_{1} X_{1}+b_{2} X_{2}+e
$$

Keterangan :

$\mathrm{Y}=$ Pembiayaan Musyarakah

$\mathrm{b}_{0}=$ Konstanta

$\mathrm{X}_{1}=$ Dana Pihak Ketiga

$\mathrm{X}_{2}=$ Non Performing Financing

$\mathrm{e}=$ error

Teknik yang dilakukan dalam menyimpulkan hasil penelitian akan menggunakan SPSS

1. Uji Asumsi Klasik

Uji asumsi klasik diperlukan untuk dapat melakukan analisis regresi berganda Pengujian tersebut dilakukan untuk menghindari atau mengurangi bias atas hasil penelitian yang diperoleh. Pengujian asumsi klasik yang digunakan dalam penelitian ini meliputi uji normalitas, uji multikolinearitas, uji autokorelasi (Erlina, 2011:102)

2. Uji Hipotesis

a. Koefisien Determinasi $\left(\mathrm{R}^{2}\right)$ untuk menentukan apakah model regresi cukup baik digunakan, maka ditetapkan melalui koefisien determinasi. Nilai adjusted $\mathrm{R}^{2}$ dapat naik atau turun apabila satu variabel independen ditambahkan ke dalam model regresi (Ghozali,2006:87).

b. Uji Statistik F pada dasarnya menunjukkan apakah semua variabel independen yang dimasukkan dalam model mempunyai pengaruh secara simultan terhadap variabel dependen.

c. Uji Statistik t pada dasarnya menunjukkan seberapa jauh satu variabel independen secara individual atau parsial dapat menerangkan variasi variabel terikat. 


\section{HASIL DAN PEMBAHASAN}

Sebelum melakukan uji hipotesis, terlebih dahulu dilakukan uji asumsi klasik. Dari hasil uji asumsi klasik diperoleh hasil bahwa uji normalitas, uji multikolinieritas dan uji autokorelasi telah terpenuhi.

\section{Uji Koefisien Determinasi $\left(R^{2}\right)$}

Hasil uji koefisien determinasi dapat dilihat pada Tabel 1.

\begin{tabular}{lrrrr}
\multicolumn{6}{l}{ Tabel 1. Hasil Koefisien Determinasi } \\
\hline $\begin{array}{l}\text { Mod } \\
\text { el }\end{array}$ & $\mathrm{R}$ & $\begin{array}{l}\mathrm{R} \\
\text { Squa } \\
\text { re }\end{array}$ & $\begin{array}{l}\text { Adjust } \\
\text { ed } \mathrm{R} \\
\text { square }\end{array}$ & $\begin{array}{l}\text { Std. Error of the } \\
\text { Estimate }\end{array}$ \\
\hline &, 58 &, 34 &, 30 & 12113492,1 \\
1 & $5^{\mathrm{a}}$ & 2 & 2 & 2115 \\
\hline
\end{tabular}

b. DependentVariable: Y

Sumber : Data sekunder diolah, Tahun

2017

Dari Tabel 1 menunjukkan nilai $\mathrm{R}$ Square sebesar 0.302 , berarti $30.2 \%$ variasi pembiayaan musyarakah dijelaskan oleh variasi variabel independen yaitu DPK dan NPF. Sisanya $69.8 \%$ dipengaruhi variabel lain yang tidak dijelaskan dalam model penelitian ini.

\section{Uji Simultan (Uji-F)}

Hasil uji simultan (Uji F) dapat dilihat pada Tabel 2 .

Tabel 2. Hasil Uji-F

ANOVA ${ }^{a}$

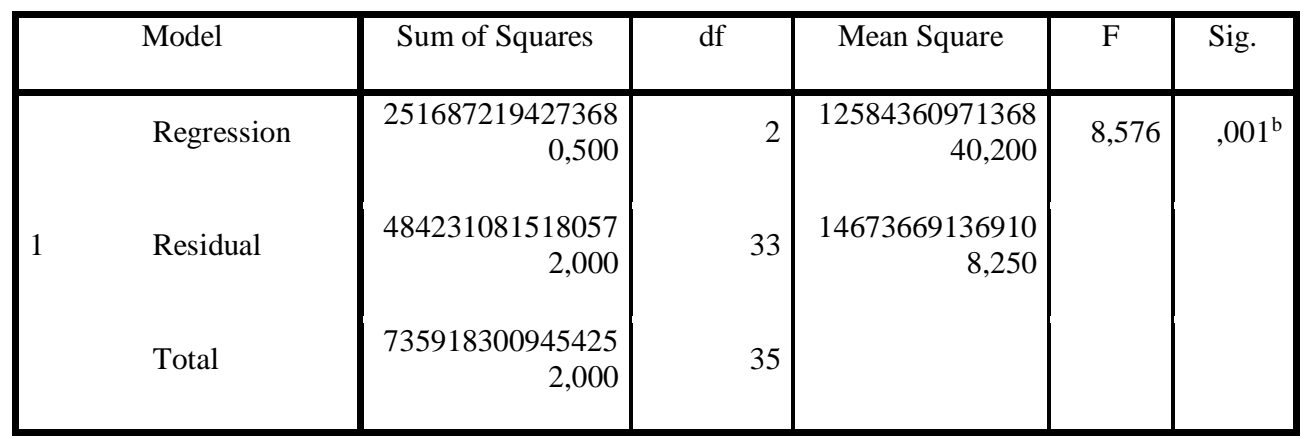

a. Dependent Variable: Pembiayaan Musyarakah

b. Predictors: (Constant), Non Performing Financing, Dana Pihak Ketiga

Dari Tabel 2, diperoleh nilai signifikansi 0,001. Dengan demikian dapat disimpulkan, sebesar $0,001<\alpha$ $(0,05)$ yang berarti $\mathrm{H}_{\mathrm{a}}$ diterima yang menyatakan bahwa DPK dan NPF secara simultan berpengaruh signifikan terhadap pembiayaan musyarakah.

\section{Uji Parsial (Uji-t)}

Hasil uji parsial (Uji-t) dapat dilihat pada Tabel 3.

Tabel 3. Hasil Uji-t

\section{Hasil Uji-T}

Coefficients $^{\mathrm{a}}$

\begin{tabular}{|c|c|c|c|c|r|}
\hline \multirow{2}{*}{ Model } & \multicolumn{2}{|c|}{ Unstandardized Coefficients } & \multicolumn{1}{|c|}{$\begin{array}{c}\text { Standardized } \\
\text { Coefficients }\end{array}$} & \multirow{2}{*}{ Sig. } \\
\cline { 2 - 5 } & B & Std. Error & Beta & & \\
\hline 1 & 104688387,944 & 9235778,382 & & 11,335 &, 000 \\
\hline
\end{tabular}




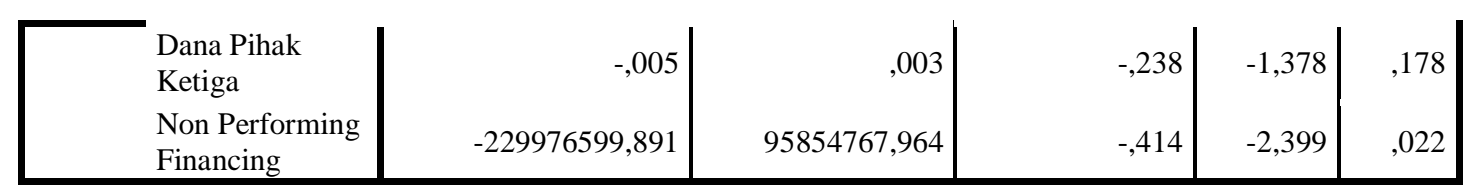

a. Dependent Variable: Pembiayaan Musyarakah

Dari Tabel 3, menghasilkan pengaruh masing-masing variabel independen terhadap variabel dependen secara parsial adalah sebagai berikut:

1. Nilai signifikansi DPK sebesar 0,178 lebih besar dari $\alpha(0,05)$, maka $\mathrm{H}_{\mathrm{a}}$ ditolak. Pengaruh DPK terhadap Pembiayaan Musyarakah adalah negatif dan tidak signifikan secara parsial.

2. Nilai signifikansi pada NPF sebesar 0.022 lebih kecil dari $\alpha$ (0,05), maka $\mathrm{H}_{\mathrm{a}}$ diterima. Pengaruh NPF terhadap Pembiayaan Musyarakah adalah negatif dan signifikan secara parsial.

Model persamaan regresi di atas sebagai berikut :

$$
\begin{aligned}
& \mathrm{Y}=104688387,944-0,005 \mathrm{X}_{1}- \\
& 229976599,891 X_{2}+e
\end{aligned}
$$

\section{Pengaruh Dana Pihak Ketiga (DPK) Terhadap Pembiayaan Musyarakah}

Dari hasil penelitian ini, bahwa

Dana Pihak Ketiga (DPK) dalam penelitian ini berpengaruh negatif dan tidak signifikan terhadap pembiayaan musyarakah Hasil penelitian ini tidak sesuai dengan teori yang dikemukakan oleh Nurjaya (2011: 65) "Semakin banyak DPK yang dihimpun maka akan semakin besar pula tingkat pembiayaan yang akan disalurkan kepada masyarakat". Sebaliknya, semakin rendah DPK yang dihimpun maka akan semakin rendah pula tingkat pembiayaan yang disalurkan kepada masyarakat.

Pada Bank Syariah Mandiri KCP Medan Sukaramai dana pihak ketiga berpengaruh negatif dan tidak signifikan disebabkan karena adanya pembengkakan pembiayaan yang lain terjadi seperti pembiayaan mudharabah, pembiayaan murabahah dan produk Bank Syariah Mandiri lainnya juga biaya operasional bank. Sehingga mengharuskan bank mengeluarkan dengan jumlah biaya yang cukup besar.

\section{Pengaruh Non Performing Financing Terhadap Pembiayaan Musyarakah}

Dari hasil penelitian ini, bahwa Penelitian ini menunjukkan hasil pengujian bahwa Non Performing Financing berpengaruh negatif dan signifikan terhadap pembiayaan musyarakah. Artinya, semakin tinggi Non Performing Financing di Bank maka akan berdampak pada penurunan pembiayaan musyarakah.

Hasil penelitian ini sesuai dengan teori yang dikemukakan oleh Nurjaya (2011:61), "Semakin tinggi rasio NPF maka semakin rendah pembiayaanmusyarakah".Sebaliknya, Semakin kecil rasio NPF akan semakin baik pembiayan musyarakah karena minimnya kredit atau pembiayaan yang gagal bayar. 
Dimana gagal bayar pada suatu bank merupakan sinyal negatif bagi bank yang bersangkutan.

\section{KESIMPULAN}

Berdasarkan hasil pengujian asumsi klasik dan hipotesis menghasilkan kesimpulan sebagai berikut :

1. Secara simultan dana pihak ketiga dan non performing financing berpengaruh terhadap pembiayaan musyarakah pada Bank Syariah Mandiri KCP Sukaramai

2. Secara parsial dana pihak ketigaberpengaruh negatif dan tidak signifikan terhadap pembiayaan musyarakah sedangkan Non performing financing berpengaruh negatif dan signifikan terhadap pembiayaan musyarakah pada Bank Syariah Mandiri KCP Sukaramai

\section{DAFTAR PUSTAKA}

Al-Qur'anul Karim dan terjemahannya. Tafsir

Ascarya. 2008. Akad dan Produk Bank Syariah. Jakarta : PT. Raja Grafindo Persada.

Budi Satrio, Tio. 2015. Pengaruh Non Performing Financing (NPF) dan Tingkat Bagi Hasil terhadap Pembiayaan Bagi Hasil Bank Unit Syariah yang terdaftar di Bank Indonesia. Surabaya : Skripsi Sekolah Tinggi Ilmu Ekonomi Perbanas.

Dendawijaya, Lukman. 2009. Manajemen Perbankan. Jakarta : Ghalia Indonesia.

Destiana, Rina. 2016. Analisis Dana Pihak Ketiga (DPK) dan Risiko terhadap Pembiayaan Mudharabah dan Musyarakah
Pada Bank Syariah di Indonesia. Cirebon : Skripsi Universitas Swadya Gunung Jati.

Erlina. 2008. Metode Penelitian Bisnis untuk Akuntansi dan Managemen. Medan : USU PRESS.

Ghozali, Imam. 2009. Aplikasi Analisis Multivariate Dengan Program SPSS. Semarang: Badan Penerbit Universitas Diponegoro.

Kasmir. 2008. Pemasaran Bank. Jakarta : Prenada Media Group.

Naf'an. 2014. Pembiayaan Musyarakah dan Mudharabah. Yogyakarta : Graha Ilmu.

Novi Pratama, Wuri Arianti. 2011. Analisis Pengaruh Dana Pihak Ketiga (DPK), Capital Adequacy Ratio (CAR), Non Performing Financing (NPF), dan Return On Asset (ROA) terhadap pembiayaan pada Perbankan Syariah. Semarang : Skripsi Fakultas Ekonomi Universitas Diponegoro.

Nurjaya, Endang. 2011. Analisis Pengaruh Inflasi, SWBI, NPF, dan DPK terhadap Pembiayaan Murabah Pada Bank Syariah di Indonesia (Periode Januari 2007-Maret 2011). Jakarta : Skripsi UIN Syarif Hidayatullah.

Nurhayati, Sri dan Wasilah. 2014. Akuntansi Syariah Di Indonesia. Jakarta : Salemba Empat.

Pandia, Frianto. 2012. Manajemen Dana dan Kesehatan Bank. Jakarta Rineka Cipta.

Rivai, Veithzal. 2008. Islamic Financial Management : Teori, konsep, dan Aplikasi. Jakarta : PT. Raja Grafindo Persada.

Rivai, $\quad$ Veithzal. 2012. Kepemimpinan dan Perilaku 
Akuntansi. Jakarta : PT. Raja Grafindo Grasida.

Sugiyono. 2010. Metode Penelitian Kuantitaf Kualitatif dan RND. Bandung : Alfabeta.

Sugiyono. 2012. Metode Penelitian Kuantitatif Kualitatif dan RND. Bandung : Alfabeta.

Tri Putrisatya, Silva. 2016. Analisis Pengaruh DPK dan ROA terhadap Pembiayaan Musyarakah ( Studi kasus pada Bank Unit Syariah di Indonesia tahun 2010-2016). Yogyakarta : Skripsi Universitas Muhammadiyah.

Undang-Undang Republik Indonesia Nomor 10 Tahun 1998 tentang Perbankan.

Undang-Undang Republik Indonesia Nomor 21 Tahun 2008 tentang Perbankan Syariah.

Sugiyono. 2010. Metode Penelitian Kuantitatif, Kualitatif dan $R$ \& $D$. Bandung: Alfabeta. 